\title{
A filosofia da existência de Kierkegaard: background da hermenêutica de Hans-Georg Gadamer
}

\section{Kierkegaard existence's philosophy: background of Hans-Georg Gadamer hermeneutics}

DOI: 10.12957/ek.2020.45581

\author{
Dnda. Natalia Mendes Teixeira \\ natalia.nmt@gmail.com
}

UNISINOS - CAPES/PROSUP

\section{RESUMO}

A radicalização dos sentidos e movimentos do compreender na existência, esboçada por Kierkegaard, provocou e influenciou profundamente Gadamer. Este artigo intenta estimular a interpretação contínua do debate entre ambos. O dinamarquês é um dos expressivos backgrounds da hermenêutica gadameriana, tanto quanto o historicismo de Dilthey, a facticidade heideggeriana, a fenomenologia husserliana e o perspectivismo nietzschiano. Para Kierkegaard e Gadamer nem a existência nem o processo hermenêutico podem ser pré-concebidos estrutural, abstrata e objetivamente de forma normativa. Para Kierkegaard, os aspectos internos da existência só podem ser descritos através da dialética da comunicação subjetiva e, para Gadamer, o acontecer hermenêutico perpassa pelo próprio processo dialógico entre um eu [self] e um tu, situados temporal e finitamente na existência. $\mathrm{O}$ fundamento dessa relação é ético-ontológico e não teóriconormativo tal como queria a hermenêutica técnica baseada em pressupostos positivistas modelados pela dicotomia sujeito-objeto.

\begin{abstract}
The radicalization of the meaning and movements of "understanding" in existence, outlined by Kierkegaard, provoked and deeply influenced Gadamer. This article intends to stimulate the continuous interpretation of the debate between both philosophers. The Danish writer is one of the expressive backgrounds of Gadamerian hermeneutics, as well as Dilthey historicism, heideggerian facticity, husserlian phenomenology and nietzschean perspectivism. For both, Kierkegaard and Gadamer, neither existence nor hermeneutic process can be pre-conceived structurally, abstractly and objectively in a normative way. For Kierkegaard, the internal aspects of existence can only be described through the dialectic of subjective communication. For Gadamer, the "occurrence" of hermeneutic goes through a dialogic process between a "self" and a "you", temporally situated and finitely in existence. The foundation of the relationship is ethicalontological and not theoretical-normative, as intended the technical hermeneutics based on positivist assumptions and modeled by the subject-object dichotomy.
\end{abstract}

Palavras-chave: Gadamer. Kierkegaard. Hermenêutica. Filosofias da Existência. Keywords: Gadamer. Kierkegaard. Hermeneutics. Philosophies of Existence. 


\section{INTRODUÇÃO}

O dinamarquês é citado diretamente 89 vezes na Gesammelte Werke de Gadamer, mas sua influência transborda tal expressão numérica: Kierkegaard aprimorou a percepção do filósofo alemão acerca da existência e dos movimentos hermenêuticos que a atravessa. Esta influência ocorreu indiretamente a partir das referências de Heidegger e de Jaspers1 a Kierkegaard; e, diretamente, pela sua leitura de Ou-Ou: um fragmento de vida (1843). A elaboração da hermenêutica filosófica gadameriana tem, deste modo, débitos fundamentais e pouco destacados com a filosofia de Kierkegaard, os quais podemos visualizar de diversas formas. Nesta exposição nos referiremos a três deles: como Gadamer rompe com a hermenêutica tradicional - preocupada em como compreender -, para assimilar, também a partir de Kierkegaard, uma hermenêutica de caráter ético-dialógico centralmente preocupada com a pergunta ontológica o que é compreender; segundo, como ambos radicalizam a resposta ao problema hermenêutico da intenção do autor - que é um desdobramento deste movimento do compreender; terceiro, apreendendo a conexão entre a hermenêutica de Gadamer e a dialética da comunicação de Kierkegaard igualmente influenciadas pela ontologia do compreender.

\section{Os sentidos do Compreender: o Kierkegaard de Gadamer}

Ao ressignificar os sentidos do que é compreender, a obra de Kierkegaard pode ser lida como uma sutil reação às respostas epistemológica dos neokantianos e idealista dos hegelianos ao problema do fundacionalismo2. A presença do nórdico escritor na teoria

1 Jaspers faz citações completas de Kierkegaard na Psicologia das Visões de Mundo (1967); Heidegger no curso de verão sobre Agostinho e em Ser e Tempo (2002).

2 A partir dos anos 1840, a Alemanha assistiu a uma crise de identidade da Filosofia diante da derrocada do programa fundacionalista dos idealistas e da ascensão das ciências empíricas que levou a questionamentos sobre método e objeto, forma e conteúdo do exercício acadêmico da Filosofia. O objetivo dos primeiros era arrogar à Filosofia a qualidade de fundadora e sistematizadora das Ciências, como proposta por Reinhold (em Elementarphilosphie); Fichte (Wissenschaftslehre); Scheling (System der 
do famoso discípulo de Heidegger ganha destacada expressão a partir da crítica que Kierkegaard desempenha a Hegel 3 quando este identifica absolutamente Ser e Pensar - e, portanto, Objeto e Sujeito. Hegel aponta identificação, e Kierkegaard, relação disjuntiva intransponível. O ganho interpretativo fornecido por Kierkegaard ao debate, sob a pena de Climacus, é a distinção entre Ser ideal e Ser factual. A dialética hegeliana opera a transição de um para o outro, ou melhor, a identificação absoluta entre eles. Kierkegaard, ao contrário, rejeitava uma ontologia que pressupunha coextensividade entre Ser e Pensar, concluindo pela radical diferença entre a existência qua existência e a existência enquanto pensada. Ao ser representada no intelecto, a existência é transmutada em conceito e, como tal, em possibilidade, mas não em atualidade. Portanto, é impossível construir teoricamente um "Sistema da Existência" dado que ele teria que ser visto sub specie aeterni4, isto é, a partir de onde o ideal não pode ser outra coisa que não o próprio ser qua ser. A existência é qualitativamente diferente do pensamento e não pode ser conhecida ou pensada pelo sujeito sem a qualidade do ideal. O ser pensado não é o ser real, é o possível, um ser mental: "assim, eu sempre raciocino desde a existência, não em direção à existência, quer me mova na esfera do fato sensível palpável ou no reino do pensamento" (KIERKEGAARD, 2011, p.68). A radicalização da filosofia kierkegaardiana ante à hegeliana é que, o pensador da existência é, antes de tudo, um existente refletindo a partir dela.

Gadamer, fundamentando-se nessa crítica, descreve Hegel como: "o professor absoluto de Berlim que esqueceu o existir" (GADAMER, 2002, p.110 [112]). Com a constatação dessa fissura no projeto hegeliano, ele radicaliza sua Hermenêutica a partir de uma nova perspectiva sobre o que é compreender: "Estava familiarizado com a crise

gesammten Philosophie) e Hegel (na Enzyklopadie). Com a falência do projeto, a Filosofia enfrenta o problema de responder ao estatuto de seu próprio exercício. Para uma descrição mais contextual desse problema do século XIX, conferir: BEISER, 2018.

3 Kierkegaard opera, no Pós-escrito conclusivo não científico às Migalhas Filosóficas (1846), uma crítica tanto aos hegelianos dinamarqueses de seu tempo quanto a esse aspecto específico da proposta hegeliana aqui descrito. Sobre os desdobramentos internos e limites da relação Hegel-Kierkegaard, conferir: STEWART, 2003.

4 I.e., "do ponto de vista da eternidade" (KIERKEGAARD, 2013, p. 84, 179, 202, 229, 238) 
do idealismo, que irrompeu na minha juventude com a retomada da crítica de Kierkegaard a Hegel. Essa imprimiu uma direção totalmente diversa ao sentido do que é compreender" (GADAMER, 2002, p.17 [10] - grifo nosso). O reaparecimento da querela Kierkegaard-Hegel na juventude de Gadamer, contra as indicações do tempo, provocoulhe uma releitura sobre o fundamento dialógico da hermenêutica. O produto da sua leitura foi que a ação produtiva do acontecer da compreensão executada pelo indivíduo subjetivamente existente, como um homo hermeneuticus5, deixa então de ser apenas uma ação metodologicamente vigiada, mas implica um movimento existencial que não pode ser inteiramente captado em um método objetivo, pois - como a citação acima continua - no lugar de um objeto puro de investigação, está ali:

\begin{abstract}
$\mathrm{O}$ outro que rompe com a centralidade do meu eu, à medida que me dá a entender algo. Esta motivação orientou-me desde o princípio (...). Tinha em mente, no entanto, o fenômeno específico do outro e buscava consequentemente no diálogo a fundamentação de nossa orientação no mundo pelo elemento da linguagem. Com isso abriu-se para mim um âmbito de questões que era do meu interesse desde os primórdios, desde Kierkegaard (GADAMER, 2002, p.17 [10] - grifo nosso).
\end{abstract}

Torna-se particularmente interessante que o "fenômeno específico do outro" seja retroalimentado no jovem Gadamer justamente a partir da leitura de Kierkegaard injustamente recepcionado como um solipsista e subjetivista nos manuais de Filosofia. Ao contrário, para Gadamer, "a renovada influência do pensamento de Kierkegaard [...] desenvolveu a perspectiva do tu, do outro eu" (GADAMER, 2002, p. 126 [104]). Esta relação $e u$-tu visualizada no interior da existência só poderia assumir um movimento dinâmico e de bases ética, ontológica e existencial e não pela identificação sujeito-objeto que assume um método puramente instrumental incapaz de captar os movimentos do acontecer hermenêutico.

Gadamer conclui isto, eu sugiro, especialmente pela sua experiência de leitura de $\mathrm{Ou}$-Ou (1843). O editor-pseudônimo Victor Eremita reúne os papéis de A e B, respectivamente o esteta e o ético. Kierkegaard apresenta estas duas estruturas de desenvolvimento da existência a partir da narrativa dessas personagens. Ao escrever sobre o esteta Kierkegaard o incorpora, ao falar das beneficies do casamento e dos deveres,

5 Expressão cunhada pelo professor Dr. Luis Rohden apresentada na disciplina Fenomenologia e Hermenêutica, UNISINOS, em outubro de 2018. 
Kierkegaard encarna o ético. A obra termina em aporia. Kierkegaard não aparece ao fim para dizer qual a resolução de vida é justificável. A resolução é do leitor. Ele o conduz a uma maiêutica da interpretação. Ou, como diz Gadamer: "está ali o outro que rompe com a centralidade do meu eu, à medida que me dá a entender algo" (GADAMER, 2002, p.17 [10]) e, novamente, a compreensão é "como um projetar-se para possibilidades de si próprio” (GADAMER, 2002, p. 125). O método de Kierkegaard ressalta a supremacia do contato do leitor com o texto e coloca a intenção da apropriação subjetiva, que é uma para cada um, acima de conclusões e construções de sistemas teórico-filosóficos abstratos. A forma literária não esvazia o conteúdo teórico, é condição para ele. Essa relação eu-tu, autor-leitor não instrumentalizada e na forma de um diálogo é mercatória na leitura de Gadamer sobre o dinamarquês.

A descrição de Gadamer sobre suas influências ilustra o papel de Kierkegaard nesse processo:

\begin{abstract}
O problema hermenêutico alcançou sua radicalização filosófica quando as ideias de Dilthey e Kierkegaard passaram a fundamentar a filosofia existencial. Foi quando Heidegger formulou o conceito de uma "hermenêtica da facticidade", impondo [...] a tarefa paradoxal de interpretar a dimensão "imemorial" (Schelling) da "existência" e inclusive a própria existência como "compreensão" e "interpretação", ou seja, como um projetar-se para possibilidades de si próprio. Nesse momento, alcançou-se um ponto no qual o caráter instrumentalista do método, presente no fenômeno hermenêutico, teve de reverter-se à dimensão ontológica. "Compreender" não significa mais um comportamento do pensamento humano dentre outros que se pode disciplinar metodologicamente, conformando assim a um procedimento científico, mas perfaz a mobilidade de fundo da existência humana (GADAMER, 2002, p. 125 [103]).
\end{abstract}

Gadamer está, nesta citação, expondo seu escopo de backgrounds: o historicismo de Dilthey, a hermenêutica da facticidade heideggeriana, a influência de Schelling e de Husserl somam-se à filosofia da existência de Kierkegaard. A partir dessas influências, ao invés de propor um novo método hermenêutico técnico e acabado, Gadamer faz, como destacado, uma investigação ontológica dos movimentos que a compreensão assume no interior da existência: a compreensão "perfaz a mobilidade de fundo da existência humana" (GADAMER, 2002, p. 125 [103]). Mais que hermenêutica, sua preocupação era 
por uma filosofia do compreender realçada da filosofia da existência de Kierkegaard à analítica existencial de Heidegger6.

Outra menção a Kierkegaard mostra que o interesse pela sua obra renasce na Alemanha exatamente por fornecer uma habilitação do diálogo como caminho para a verdade:

\begin{abstract}
Não foi por acaso que um discípulo do romantismo alemão, o escritor dinamarquês Søren Kierekgaard, dotado de grande maestria literária, tenha travado uma batalha nos anos quarenta do século XIX contra o predomínio acadêmico do idealismo hegeliano. No século XX, com a tradução de suas obras para o alemão, Kierkegaard passou a exercer grande influência na Europa. Foi sobretudo aqui em Heidelberg (mas também em muitos outros locais da Alemanha) que o pensamento começou a contrapor a experiência de um tu e da palavra que une um eu e um tu ao idealismo neokantiano. $\mathrm{O}$ renascimento de Kierkegaard em Heidelberg, promovido sobretudo por Jaspers, teve forte expressão na revista Die Kreatur (A criatura). Homens como Franz Rosenzweig e Martin Buber, Friedrich Gogarten e Ferdinand Ebner, para citar apenas alguns pesadores judeus, protestantes e católicos (...) uniram-se na convicção de que o caminho da verdade passa pelo diálogo (GADAMER, 2002 , p. $247[211]) 7$.
\end{abstract}

Se para Kierkegaard, em termos gadamerianos, a existência é a contínua compreensão dialógica do eu-tu; esta será, então, para Gadamer com a leitura de Kierkegaard, não reduzida às capacidades e faculdades cognitivas ou a um adestramento metodológico da compreensão da existência. A hermenêutica acompanha o próprio mover da existência e, portanto, não cabe em um método hermético ou num receituário. Foi, então, neste contexto que a hermenêutica técnica tradicional, com seus desdobramentos instrumentalistas baseados no como compreender que alçava a objetividade interpretativa assumiu, em Gadamer, uma dimensão ontológica voltada ao sentido do que é compreender, preocupada com o movimento orgânico do processo interpretativo. Se Kierkegaard olha a dinamicidade da relação eu-tu no interior da existência; Gadamer no interior do diálogo, da interpretação, da leitura, da relação autor/leitor, texto/leitor e no meio disso percebe a linguagem operando no interior da vida humana e separando-a das demais formas de vida - o logos é caracteristicamente humano;

\footnotetext{
6 "A caracterização e ênfase que Heidegger atribui à compreensão como mobilidade de fundo da existência culmina no conceito de interpretação" (GADAMER, 2002, p. 125 [103]).

7 Mais sobre o tema da recepção das traduções: VALLS, A. Ein, Zwei, Drei, Kierkegaard Entre os Professores Alemães. In: Kierkegaard Compêndio, Volume 2. São Paulo: LiberArs, 2019, p. 9-44.
} 
Kierkegaard a usa magistralmente para narrar a personificação e as fissuras das categorias da existência e Gadamer para expor o acontecer do processo interpretativo no interior dela.

No tópico seguinte, vejamos como este movimento de compreensão se expressa na relação escritor e leitor tornando-se ponto decisivo no projeto filosófico de ambos: de Kierkegaard, por sua própria relação com o leitor; de Gadamer, por sua interpretação dessa relação.

\section{O problema da intenção: a morte do autor é o nascimento do leitors?}

A hermenêutica elaborada por Schleiermacher entendia que: 1) A intenção do autor determina o significado de um texto; 2) Que esta intenção deve ser buscada gramatical e psicologicamente. $\mathrm{O}$ texto seria, portanto, a fiel expressão exterior do sentido interno que está fixado e completo na mente do autor antes mesmo de escrever. A leitura deve conter, assim, um aspecto divinatório, comparativo e requer uma condição de congenialidade que possa reproduzir o estado interior do autor na mente do leitor que acessa o texto:

\footnotetext{
A principal tarefa da interpretação gramatical é, então, conforme o pressuposto conhecimento do significado, encontrar para cada caso dado o verdadeiro uso que o autor tinha em mente, evitando tanto os falsos como também o muito e o pouco (SCHLEIERMACHER, 2010, p.79 - grifo nosso)
}

Não apenas o aspecto gramatical, mas também o psicológico (Schleiermacher, 2010, p.41-42), a partir da pessoalidade do autor e de seu processo intelectual devem ser ajustados de modo a compor o pensamento do autor em uma reconstrução racional cujo pressuposto é o resgate absoluto de aspectos tanto extrínsecos como intrínsecos ao texto. A hermenêutica requer uma práxis laxista, um conjunto de dogmas reunidos num cânone de regras gramaticais e psicológicas de interpretação. Seu método não aceita a restrição imposta nem pela tradução nem pelo autor. Nas palavras de Gadamer, para Schleiermacher "O que deve ser compreendido não é a literalidade das palavras e seu

\footnotetext{
8 Referência a um dos temas do pós-modernismo francês de Roland Barthes, Michel Foucault e Jacques Derrida. Corriqueiramente a Filosofia de Gadamer é oposta a esta tradição - como feito, por exemplo, em Dialogue and Deconstruction: The Gadamer-Derrida Encounter, Ed. Diane P. Albany: Suny Press, 1989. No entanto, os entrelaçamentos teóricos entre ambas as tradições merecem maior atenção.
} 
sentido objetivo, mas também a individualidade de quem fala e, consequentemente, do autor” (GADAMER, 2015, p.290 [189]) ao retroceder à gênese da ideia do autor.

Para Gadamer, por outro lado, o critério de compreensão de uma obra não é, de modo algum, a intenção do autor. $\mathrm{O}$ autor pode ter tido em mente muito mais do que se pode compreender (GADAMER, 2015, p. 287 [187]). Ele está : 1) Preocupado com as condições de possibilidade de toda compreensão e não com o aspecto normativo do método; 2) Elaborando uma teoria que destaca o papel dos pré-conceitos, juízos que transcendem o próprio método, de forma a reabilitá-los - já que não se pode abandonálos completamente - pois a compreensão é também fornecida por eles. Tais preconceitos são fornecidos pela própria condição epistemológica e psicológica do intérprete, mas também pela tradição em que ele se encontra:

\footnotetext{
Cada época deve compreender a seu modo um texto transmitido, pois o texto forma parte do todo da tradição na qual cada época tem um interesse objetivo e onde também ela procura compreender a si mesma. Como se apresenta a seu intérprete, o verdadeiro sentido de um texto não depende do aspecto puramente ocasional representado pelo autor e seu público originário. Ou pelo menos não se esgota nisso, pois sempre é determinado também pela situação histórica do intérprete e consequentemente por todo curso objetivo da história (GADAMER, 2016, p. 392, [302])
}

A compreensão é, assim, um jogo entre a expectativa de sentido que projetamos no texto e o aprimoramento que o texto fornece paulatinamente, um cotejamento infinito entre o que foi lido e o que foi escrito. Assim, a resposta de Gadamer à Schleiermacher é que a intenção do autor em nada interfere para a compreensão do texto; o objeto de interpretação é tão-só o próprio texto mediado pelos pré-conceitos, pela tradição e pelo que ao intérprete ascende como verdadeiro. A relação é do intérprete com o texto, e não com as condições psicológicas do autor, inacessíveis a ele próprio. Gadamer discorda, assim, que o movimento interpretativo divinatório e congenial seja possível.

Kierkegaard, como autor consciente dessa impossibilidade movimenta o leitor, através dos pseudônimos, para o interior de um diálogo com ele próprio: esta é sua intenção. Embora sua reação à hermenêutica schleiermacheriana possa ser lida de forma controversa, alguns trechos sugerem sua posição. Na parte final do Pós-escrito intitulada Adendo: o entendimento com o leitor, Kierkegaard igualará a tentativa do autor de ser "compreendido" como uma revogação da obra: "escrever um livro e revogá-lo não é algo 
mais que deixar de escrevê-lo" (KIERKEGAARD, 2016, p. 337). Aqui está a essência do que é compreender para Kierkegaard.

Outro aspecto, um pouco mais marginal, porém representativo é que Kierkegaard na sua relação com o leitor, via-se movido pelo escrito da não-autoridade. Isto quer dizer, em primeira instância, que ele próprio não reivindicava a autoridade eclesiástica, estatal ou acadêmica - nem mesmo prodigalizava a credencial de sua genialidade literária que o aprovaria por seu próprio talento. Por isso, ele escreve, muitas vezes, usando expressões pouco pretensiosas: os Discursos Edificantes não são sermões ou doutrinas; as Migalhas Filosóficas não são sistemas filosóficos; o Pós-escrito não científico não parte de altas pretensões científico-acadêmicas; todas são expressões de como ele se desautorizava da última palavra como escritor, não se colocando epistemologicamente acima de seus leitores, mas sim, no mesmo lugar de compreensão que eles. O escritor é um companheiro de interpretação do leitor; como no experimento A, das Migalhas, o "mestre é apenas a ocasião que faz o aprendiz" (KIERKEGAARD, 2011, p.32)9 e não o centro do aprendizado, da interpretação. Em muitas ocasiões, sob a voz de diferentes pseudônimos, Kierkegaard pareceu inclusive abrir mão da tarefa de ser compreendido. No prefácio às Migalhas Filosóficas, sob a pena de Climacus, afirma:

\footnotetext{
9 Torna-se significativo que ele trate sobre o compreender nesta obra porque é exatamente onde ele descreve a relação mestre/discípulo. No experimento A, ele postula a tese de que o mestre é a ocasião para a verdade e esta depende inteiramente do esforço, da apropriação do discípulo - como dito no Pós-escrito, a verdade é subjetividade porque é apropriação do indivíduo. Esta exposição de Kierkegaard se desdobra - ainda que restritamente - também na crítica de Gadamer ao atual estado do diálogo pedagógico (GADAMER, 2002, 242-254) e aos círculos acadêmicos nos quais o mestre entende que quanto mais articulada é sua fala, ainda que monológica e unilateral, mais está se comunicando com seus alunos. Este é o "perigo da cátedra", denunciado por Gadamer, que afasta o aluno do diálogo e o coloca sob a égide de um monólogo - aspecto inclusive que ele pontua como motivo da decadência atual do ensino das Ciências. Assim, a ascendente incapacidade para o diálogo nas ciências e na sociedade tem fundamento na própria concepção social e científica do que é compreender. Gadamer critica nossos seminários acadêmicos, nossas mesas - que tem em sua essência um diálogo já morto, nulo, não efetivo - porque o aspecto dialógico da comunicação não se dá na presença de muitos. Na mesma esteira Kierkegaard defende que na multidão habita a não verdade (KIERKEGAARD, 1997, p. 292)
} 
Ter uma opinião é ao mesmo tempo demais e de menos para mim. Ter uma opinião pressupõe uma existência segura e confortável [...] eu não tenho doutrina a oferecer [...] qualquer ser humano me é pesado demais; e por isso, eu suplico, per deos obsecro, que ninguém se incline diante de mim (KIERKEGAARD, 2011, p.22-23).

Ele está renunciando à pretensão de se ter uma opinião última sobre qualquer tema que ele próprio tenha desenvolvido. Em outro prefácio, desta vez no Pós-escrito às Migalhas, ao falar das Migalhas não terem despertado reação alguma nos críticos e nos leitores: "sem qualquer alvoroço, sem derramamento de sangue nem de tinta, o opúsculo permaneceu não noticiado (...) o autor, qua autor, está também na afortunada posição de não dever absolutamente nada a ninguém” (KIERKEGAARD, 2013, p. 11-12). Ou, nas palavras de Silentio implicando também Hegel: "o presente autor de nenhum modo é um filósofo. Não entendeu o sistema, nem se o sistema existe ou se já acabou" (KIERKEGAARD, 2009, p. 52). Ora, Kierkegaard está renunciando a posição de filósofo - especialmente se filosofia implicar necessariamente sistema - e à possibilidade de ter uma filosofia acabada a qual o leitor deveria entrar em contato imediato.

Da mesma forma, como vimos, Gadamer entende que as obras: "se desligam de suas origens e, justamente por isso, começam a falar - surpreendendo até mesmo seus criadores (...) nem a palavra nem a sentença nem, como se diria hoje, o discurso, remete para a intenção do autor" (GADAMER, 2002, p. 296 [255]). Isso ocorre porque a intenção do autor ao ser materializada na obra não pode mais ser buscada depois dela, e mesmo antes dela não está de todo clara para o próprio autor. Esta ideia está totalmente de acordo com a filosofia de Kierkegaard que vê o homem como corporalmente situado e, por isso, com uma perspectiva finita e mutável; e a de Gadamer que também tem a compreensão como guiada e limitada pela própria condição finita do sujeito que compreende. O leitor figura como um participante no enredo da exposição podendo vivenciá-lo de acordo com a sua própria situação na temporalidade e na finitude. Este aspecto é central para Gadamer: "devemos fixar-nos no ponto de partida da finitude10” (GADAMER, 2002, p.172 [105]). A afirmação da finitude, em ambos, é também levantada como crítica ao idealismo especulativo que se torna infinito na reflexão e na abstração sem retornar à vida

10 Outros momentos de desenvolvimento do conceito de Finitude em Gadamer, Cf. VMI: 125, 137, 236, 280, 363, 461, 475, 483; e VMII: 28, 40, 54, 331, 333, 470. 
fática11. O texto, assim, como extrato da finitude humana, não pode ter um significado único, imutável e infinito; a intenção é inescrutável.

Com isso, Gadamer e Kierkegaard, embora concordem que a compreensão já pertence ao ser daquilo que é compreendido, entendem que ler um texto é traduzi-lo e não existe uma única tradução que seja a reduplicação correta da intenção do autor. Compreensão não é meramente uma reprodução técnica, é um ato produtivo. $\mathrm{O}$ autor precisa sempre do leitor como coprodutor desse sentido. A morte do autor é o nascimento do leitor, e isso aponta para a eternidade, a inescrutabilidade dos vários sentidos de um texto e para a temporalidade e finitude humanas. A compreensão é um processo, um movimento que não termina12 e este aspecto fundamental da hermenêutica de Gadamer ele deve essencialmente também à Kierkegaard.

\section{A Dialética da Comunicação de Kierkegaard e a Hermenêutica de Gadamer}

Como vimos, os desdobramentos do compreender alcançam o problema da intenção do autor e nele encontram significativa expressão. Mas além da relação escritor/leitor outra importante influência sobre Gadamer é o jogo de pseudônimos 13 de Kierkegaard. Os pseudônimos eram narradores que fazia autoexperimentos e comunicavam aspectos particulares da existência que não podiam ser, ao menos coerentemente, expostos de outra forma - e não disfarce da autoria de Kierkegaard. O jogo de máscaras detém a intenção de desvelar individualmente para cada leitor aspectos particulares da existência. Kierkegaard está apontando para a contradição de se apresentar a realidade subjetiva de forma objetiva a partir de sistemas categoriais abstratos - ou seja,

\footnotetext{
11 Há que se fazer aqui uma distinção: Kierkegaard entende que a dialética da existência se realiza entre a finitude corpórea humana e a infinitude do pensamento, da reflexão, da imaginação e da própria existência. Este aspecto dialético só pode ser visualizado em Gadamer restritamente vinculado ao fato de que apesar dele reconhecer a inestimabilidade da finitude, da vida fática, da situação do indivíduo na tradição, ele também ressalta a importância do aspecto teórico que parte do reino da reflexão que pode ser infinita - e que por isso mesmo precisa retornar à concreção da situação. 12 Sobre isto conferir também: GEORGE, p.114, 2015.

13 Inclusive na sua teoria dos jogos. Conferir capítulo segundo da primeira parte de Verdade e Método: “ $A$ ontologia da obra de arte e seu significado hermenêutico" (GADAMER, 2016, p.156).
} 
expor aspectos inerentes à existência humana pretensiosamente de fora dela. A pergunta de Kierkegaard é: ao ser o objeto da Filosofia o próprio sujeito, como podem os métodos das ciências empíricas, o positivismo filosófico, que olha o objeto de forma estática, servir para acessá-lo? Ou como comunicar aspectos da existência na forma da comunicação objetiva?

A comunicação indireta era, para ele, uma forma de criar personagens que falam de si a partir de si, e com os quais o leitor pode se relacionar diretamente. Alguns de seus críticos contemporâneos consideravam que escrever através de personagens criadas detinha a pretensão de fugir dos possíveis problemas de sua obra14. Ele, ao contrário, defende tratar-se de uma posição contra o escrito que fala e se fundamenta por titulação, posição, ou por argumentum ad verecundiam. Ler Kierkegaard é ler cada obra assim como ela nos é dada por cada pseudônimo, em sua totalidade, sua disposição e sua estrutura. $\mathrm{O}$ aspecto duplo da comunicação kierkegaardiana se efetiva na relação de duas interioridades situadas existencialmente em condições históricas distintas, por isso, "o caminho nasce para o indivíduo e fecha-se atrás dele" (KIERKEGAARD, 2013, p. 69) e a especulação filosófica objetiva com pretensões de universalidade não encontra tal caminho. Nela tudo se tornou tão objetivo que se argumenta o indivíduo a partir da totalidade. Kierkegaard não está desconsiderando a objetividade das ciências, mas fazendo uma distinção: o que é objetivo e o que é subjetivo pressupõe manifestações distintas na forma da comunicação. A forma direta pressupõe resultado, acabamento e certeza, mas isto é impossível para o que está em devir - e esta é a categoria sobre a qual tudo que é existencial se movimenta. A comunicação, portanto, detém uma dialética, um movimento e não se encerra objetivamente em receitas técnicas e normativas.

Através de Climacus ele traça a seguinte descrição de uma exposição direta: "quando alguém conta alguma coisa e o outro se reconhece literalmente no mesmo, supõe-se que estão de acordo e que se compreenderam um ao outro" (KIERKEGAARD, 2013, p. 77). No entanto, está-se rejeitando o caráter duplo da existência do pensamento

${ }_{14}$ Como aponta Louis Mackey "A Kierkegaardian pseudonym is a persona, an imaginary person created by the author for artistic purposes, not a nom de plume, a fictitious name used to protect his personal identity from the threats and embarrassments of publicity... his purpose was not mystification but distance". Louis Mackey, Kierkegaard: A Kind of Poet, p. 247. Sobre isto também conferir Merold Westphal, 1996. 
e, então, nega-se a dupla reflexão da comunicação e tal concordância torna-se um malentendido:

\begin{abstract}
O segredo da comunicação depende especificamente de deixar o outro livre, e, exatamente por esta razão, ele não pode comunicar-se diretamente (...) [pressupor que] a compreensão se efetiva pela comunicação direta é uma fraude (...) tanto em relação a si mesmo, quanto uma fraude em relação ao outro ser humano (KIERKEGAARD, 2013, p. 77).
\end{abstract}

A compreensão completa só pode encontrar o caminho da fraude e do equívoco. Reconhecer-se inteiramente na exposição do outro é a negação da compreensão, i.e., do próprio movimento do compreender, nas palavras de Gadamer, do acontecer hermenêutico; só há fusão de horizontes se há posições distintas, um eu e um tu delimitadamente situados:

Ser de antemão 'compreensivo' diante de todas as réplicas do outro nada mais é que tirar o corpo fora do postulado feito pelo outro. É um modo de não se deixar dizer nada. Onde porém, alguém está disposto a escutar o que o outro tem a dizer (...) ali se adquire um autoconhecimento autêntico (...) não é portanto num compreender soberano que se dá uma real ampliação desse nosso eu, confinado à estreiteza da vivência (...) mas antes no encontro com o incompreensível (GADAMER, 2002, p. 47 [35]).

Embora a fusão de horizontes diversos seja possível e necessária, ela não pressupõe a anulação da posição interpretativa particular daquele que compreende, não elimina sua condição de ser situado finitamente no mundo: "a experiência ensina que nada mais impede um verdadeiro entendimento entre um eu e um tu do que a pretensão de uma das partes de compreender o outro em seu ser e sua opinião" (GADAMER, 2002, p. 47 [35]). Esta é a primeira experiência do tu, na qual compreende-se o outro da mesma maneira que se compreende qualquer processo no campo da experiência objetiva e científica colocando o outro na posição de objeto a ser possuído pela compreensão. Este comportamento é correspondente à fé ingênua no método e na objetividade: a tradição, o outro, o texto é convertido em objeto, sem que o intérprete - que é um $e u$ - seja atingido pelo $t u$. Elimina-se, então, todo o horizonte de compreensão, o processo dialógico, o movimento do compreender. Este comportamento interpretativo é herdado do positivismo.

A proposta de Gadamer é de um entrecruzamento crítico e não de uma abertura insensata à posição do outro; ao mesmo tempo que não se trata de uma conversão do outro a objeto científico; afinal, o objeto não transforma o sujeito e uma das expressões de que 
a compreensão ocorreu é justamente a dupla transformação do $e u$ e do tu. Por isso, a relação hermenêutica é sempre sujeito-sujeito.

Kierkegaard criticara a comunicação direta, a qual: "é completamente indiferente à subjetividade e, com isso, à interioridade e à apropriação" (KIERKEGAARD, 2013, p.77). A comunicação indireta da qual ele faz uso, ao contrário, exige que se "pense no receptor e preste atenção à forma da comunicação em relação à má compreensão do receptor" (KIERKEGAARD, 2013, p.79). Com esta afirmação Kierkegaard está, também, antecipando o que Gadamer desenvolveu sobre o cuidado da mensagem para com o receptor - até que ponto o autor é responsável pela má interpretação do leitor? Assim ocorre a dialética da dupla reflexão da comunicação:

Quando o pensamento achou sua expressão correta na palavra, o que se alcança pela primeira reflexão, aí vem a segunda reflexão, que tem a ver com a própria relação da comunicação com o comunicador, e reproduz a própria relação do comunicador existente para com a ideia (KIEKEGAARD, 2013, p. 79 - grifo nosso).

$\mathrm{O}$ primeiro movimento da reflexão do compreender aglutina o pensamento à palavra; o segundo, do comunicador [sujeito] com o que foi comunicado [ideia] envolve aquilo que foi existencialmente comunicado com o próprio sujeito existente. Isto é, o que foi comunicado tem um vinculo indissociável com o próprio sujeito. Gadamer sugere um movimento semelhante entre a palavra e o conceito: "temos de caminhar não apenas da palavra ao conceito, mas do conceito à palavra" (GADAMER, 2002, p. 247 [211]) porque, "a partir da influência de Kierkegaard, o pensamento começou a contrapor a experiência de um tu e da palavra que une um eu e um tu" (GADAMER, 2002, p. 247 [211] - grifo nosso). E assim Gadamer, a partir de Kierkegaard, demonstra que o encontro de dois sujeitos não pode tomar a forma da relação sujeito/objeto das ciências.

Deste modo, constatamos que para ambos o movimento do compreender na finitude é uma relação dinâmica entre dois sujeitos situados existencialmente - seja na relação $e u$-tu, autor-leitor, eu-tradição, sujeito-sujeito em diálogo. Estes, no ato comunicativo, que não é fechado, mas dinâmico, processual e inacabado, não chegarão ao entendimento completo das posições contrárias, isto significaria reduzir o tu à condição de objeto a ser possuído interpretativamente; ao mesmo tempo que apenas pela transformação de ambas as partes é que a compreensão se mostra efetiva. 


\section{CONCLUSÃO}

Vê-se que nem a existência nem o processo hermenêutico podem ser descritos de forma normativa e pré-concebida em um protótipo técnico. Para Kierkegaard, os aspectos internos da existência só podem ser comunicados através da dialética da comunicação subjetiva e, para Gadamer, o acontecer hermenêutico perpassa o processo dialógico entre o $e u$ e o tu15. Ambas posições estão fundamentadas nos sentidos do que é compreender que se contrapõem às ciências positivas e a cientifização da filosofia e da interpretação. Esta se expressa nas posições de ambos sobre a relação autor/leitor, eu/tu, texto/leitor. Desta forma é que a filosofia e a própria pseudonímia de Kierkegaard tornaram-se importantes e inalienáveis background da filosofia hermenêutica de Gadamer. Embora o tema seja mais produtivo e mesmo controverso que apenas um artigo possa dar conta, fornecemos um extrato, um esboço que minimamente nos guia ao início da reabilitação da interpretação do debate histórico entre ambos autores.

\section{Referências bibliográficas}

BEISER, F. Depois de Hegel.: São Leopoldo, RS :Unisinos, 2017.

GADAMER, Hans-Georg. Verdade e Método I: traços fundamentais de uma hermenêutica filosófica. 6. Ed. Petrópolis, RJ: Vozes, 2016.

GADAMER, Hans-Georg. Verdade e Método II: complementos e índices. 15. Ed. Petrópolis, RJ: Vozes, 2002.

\footnotetext{
${ }_{15}$ Cujo fundamento é ético-ontológico e não teórico-normativo - base da crítica herdada de Heidegger ao humanismo essencialista. Gadamer segue a crítica ao humanismo feita por Heidegger, exposta na Carta sobre o Humanismo (2005), onde ele propõe a superação da divisão entre Ética e Ontologia para afirmar a radicalidade da nossa liberdade. A metafísica tradicional pautada no essencialismo é normativa e nela a liberdade é restrita à realização da suposta essência humana. Melhor exposição do tema está em: GEORGE, T.; DENNIS, J., 2016.
} 
GEORGE, T., DENNIS J. “The responsibility to understand”. In: HEIDEN, Gert-Jan van der. Phenomenological perspectives on plurality. Leiden: Brill, 2016. p. 103-120.

HEIDEGGER, Martin. Carta sobre o humanismo. Trad. Rubens Eduardo Farias. São Paulo: Centauro, 2005.

HEIDEGGER, Martin. Ser e tempo. Trad. Fausto Castilho. Campinas: Editora Unicamp e Vozes, 2012.

JASPERS, Karl. Psicología de las concepciones del mundo. Madrid: Editorial Gredos, 1967.

KIERKEGAARD, S. A. Migalhas filosóficas. Trad. Álvaro L. M. Valls. 3. Ed. Petrópolis, RJ: Vozes, 2011.

KIERKEGAARD, S. A. Ou Ou: fragmento de vida. Vol I. Trad. Elisabete M. de Sousa. Lisboa: Relógio D’Água: 2013.

KIERKEGAARD, S. A. Ou-Ou: fragmento de vida. Vol II. Trad. Elisabete M. de Sousa. Lisboa: Relógio D’Água: 2017.

KIERKEGAARD, S. A. Pós-Escrito Conclusivo Não Científico às Migalhas Filosóficas: Coletânea Mímico-Patético-Dialética, Contribuição Existencial, por Johannes Climacus. Tradução de Álvaro L. M. Valls. Petrópolis, RJ: Vozes; Bragança Paulista, SP: Editora Universitária São Francisco, 2013. Vol. I. (Coleção Pensamento Humano).

KIERKEGAARD, S. A. Pós-Escrito Conclusivo Não Científico às Migalhas Filosóficas: Coletânea Mímico-Patético-Dialética, Contribuição Existencial, por Johannes Climacus. Tradução de Álvaro L. M. Valls. Petrópolis, RJ: Vozes; Bragança Paulista, SP: Editora Universitária São Francisco, 2016. Vol. II. (Coleção Pensamento Humano).

KIERKEGAARD, S. A. Temor e Tremor. Lisboa: Relógio D’água, 2009.

KIERKEGAARD, S. A. The Point of View. Tradução: Howard V. Hong e Edna H. Hong. Princeton, New Jersey: Princeton University Press, 1998.

MACHEY, Louis. Kierkegaard: A Kind of Poet, Pennsylvania: University of Pennsylvania Press, 1971.

MALANTSCHUK, G. Kierkegaard's Concept of Existence. Trad. H. e E. Hong. Princeton: Marquette University Press, 2003.

MICHELFELDER, Diane P. Dialogue and Deconstruction: The Gadamer-Derrida Encounter, Ed. Diane P. Albany: Suny Press, 1989.

ROHDEN, Luiz. Hermenêutica Filosófica. São Leopoldo, RS: Unisinos, 2002. 
ROHDEN, Luiz. Interfaces da Hermenêutica: método, ética e literatura. Caxias do Sul, RS: Educs, 2008.

SCHLEIERMACHER, Friedrich. Hermenêutica: arte e técnica da interpretação. 8. ed. Petrópolis: Vozes, 2010.

SCHNÄDELBACH, Herbert. Phiolosophy in Germany, 1831-1933. Cambridge University Press; 1984 edition.

STEWART, J. Kierkegaard's relations to Hegel reconsidered, New York: Cambridge University Press, 2003.

VALLS, A. "Ein, Zwei, Drei: Kierkegaard entre os Professores Alemães". In: Kierkegaard Compêndio, Volume 2. São Paulo: LiberArs, 2019, p. 9-44.

WESTPHAL, M. Becoming a self. West Lafayette: Purdue University Press, 1996.

Recebido em: 26/09/2019 | Aprovado em: 12/05/2020 